\author{
ИНГрид МАЙЕР \\ Упсальский университет (Швеция, Упсала) \\ ingrid.maier@moderna.uu.se
}

\title{
Латинские стихотворения из Equile Ioannis Austriaci в русском переводе 1677 г. $^{1}$
}

\begin{abstract}
Введение
В Российской национальной библиотеке сохранилась серия уникальных гравюр на меди, исполненных разными фламандскими мастерами на основе рисунков известнейшего художника того времени, Яна ван дер Страта (Jan van der Straet, 1523-1605), уроженца нидерландского города Брюгге 2 . Художник прожил бо́льшую часть жизни в Италии - главным образом во Флоренции, в окружении герцогов Медичи - и был известен также под латинской и итальянской формой имени, Johannes Stradanus / Giovanni Stradano 3 (в дальнейшем мы будем пользоваться латинской формой, под которой он приобрел наибольшую известность). В 1576 г. Страданус начал служить Дону Хуану Австрийскому (Don Juan de Austria, 1547-1578), победителю турок в известной битве при Лепанто 1571 г., незаконному сыну императора Карла V и сводному брату испанского короля Филиппа II. Вместе с новым покровителем, Хуаном Австрийским, назначенным в 1576 г. генерал-губернатором Нидерландов, Страданус поехал в Южные Нидерланды, где познакомился с антверпенским художником и издателем Филиппом Галле (Philipp/Philips Galle, 1537-1612), уроженцем голландского Гарлема, с 1570 г. работавшим в Антверпене. Впоследствии Галле стал одним из самых плодовитых граверов и издателей гравюр северной Европы ${ }^{4}$. В частности, Галле выпустил целый ряд циклов гравюр по рисункам Страдануса. Это сотрудничество не закончилось

${ }^{1}$ Автор сердечно благодарит соавторов других работ о «лошадиных» переводах, Олега Русаковского и Олену Янссон, за важные замечания и всестороннюю помощь, а также латинистов Винфрида Шумахера (Winfried Schumacher, Кёльн) и Марианне Вифстранд Шибе (Marianne Wifstrand Schiebe, Упсала). Московский соавтор других работ, Андрей Гуськов, любезно помог нам с выписками из архивных документов - как потом оказалось, в последний момент перед долговременным закрытием архива, - а также с их интерпретацией. В РНБ - куда, к счастью, удалось съездить незадолго до закрытия границ в связи с борьбой против новой чумы - нам оказала ценную помощь Ольга Новикова. Ларсу Бруселиусу (Lars Bruzelius) мы очень признательны за помощь в работе с интернет-ресурсами и фотокопиями гравюр. Нидерландские искусствоведы Марьолейн Леесберх (Marjolein Leesberg) и Клазина Ботке (Klazina Botke) помогли нам в определении изданий и состояний «петербургских» гравюр. Лидия Сазонова и Татьяна Мазий внесли стилистическую правку - мы очень признательны за их помощь, оказанную в последнюю минуту при остром дефиците времени.

2 РНБ, Погодинское собрание, № 1717, л. 264-287 (согласно современной библиотечной нумерации листов), л. 275-[315] (по первоначальной кириллической фолиации). В дальнейшем даются ссылки по исходной фолиации, кириллической, если это не оговаривается специально.

3 О биографии ван дер Страта / Страдануса см., например, [Baroni 2012; Janssens 2012]. Краткую версию см. также [Oxford Art Online] (электронный ресурс).

${ }^{4}$ См. оценку Манфреда Селлинка, составителя тома о мастерской Галле в престижной серии «The New Hollstein», считавшего, что за период 1575-1585 гг. «[...] Philips Galle was without doubt the most prolific and most versatile print publisher active in Northern Europe» [Sellink 2001: LV].
\end{abstract}


даже после неожиданной смерти генерал-губернатора Хуана Австрийского в Нидерландах и последующего возвращения Страдануса в Италию. Очевидно, за «нидерландский период» 1576-1578 гг. Страданус и создал серию изображений лошадей, впоследствии гравированных рядом выдающихся фламандских граверов и впервые изданных около 1580 г. (см. [NHD Stradanus: 232]). На большинстве гравюр изображено по одной породе лошадей, якобы из конюшни Хуана Австрийского, но в серию входят также изображения мула, осла и групп лошадей неопределенных пород.

Цикл гравюр имеет титульный лист: «Eqvile Ioannis Avstriaci Caroli V. Imp[eratoris] F[ilii], In quo omnis generis generosissimorum equorum ex variis orbis partibus insignis delectus. Ad vivum omnes delineati à celeberrimo pictore Iohanne Stradano Belga Brugensi. Et à Philippo Gallęo editi5») («Конюшня Хуана Австрийского, сына императора Карла V, в которой [представлена] замечательная выборка породистых лошадей всех пород из разных частей земли. Все [они] запечатлены известнейшим художником Иоганном Страданусом, [родом] из нидерландского города Брюгге, и изданы Филиппом Галле»). Гравюры сравнительно небольшого размера, около $200 \times 260 \mathrm{Mм}^{6}$, полный лист — около $260 \times 345$ мм.

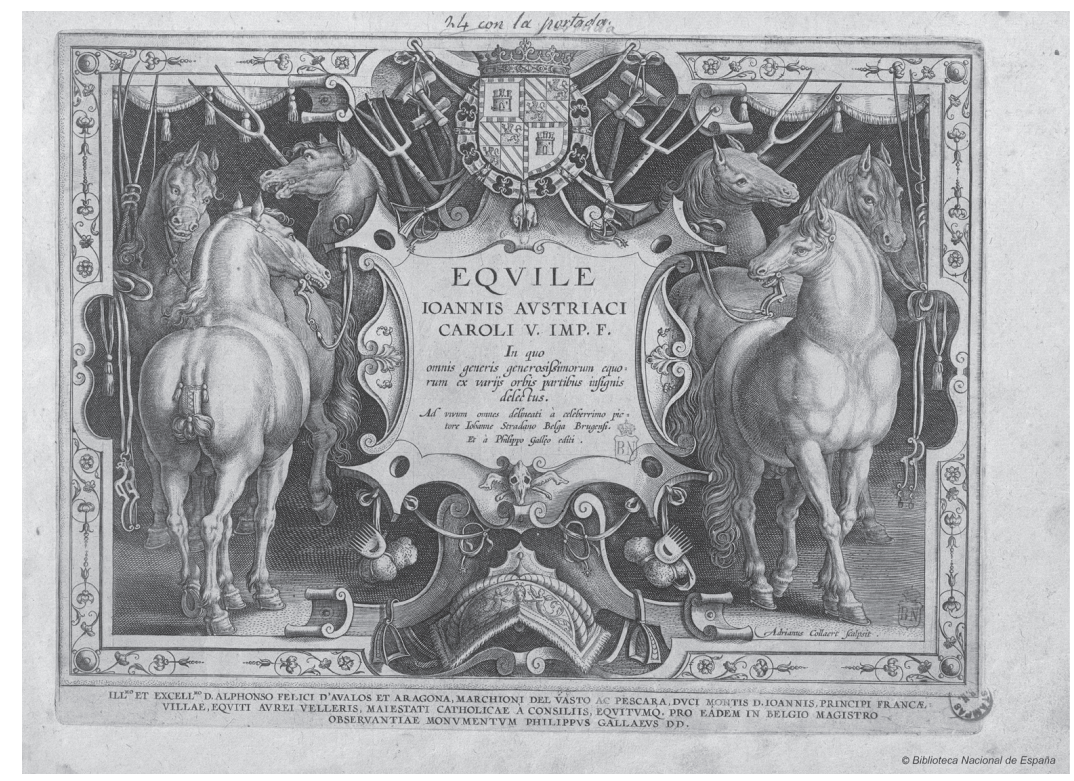

Илл. 1: Титульный лист Eqvile Ioannis Avstriaci. Национальная библиотека Испании в Мадриде ${ }^{7}$.

5 Цитируется по петербургскому экземпляру, л. 275. В дальнейшем мы будем пользоваться сокращенным названием Equile Ioannis Austriaci.

6 Размер гравюр несколько отличается от листа к листу, даже от экземпляра к экземпляру. Гравюра на титульном листе крупнее остальных - $211 \times 280$ мм.

7 Титульный лист доступен в Интернете. URL: http://bdh.bne.es/bnesearch/detalle/bdh00000 43254 (дата обращения 24.04.2020). Мадридский экземпляр идентичен находящемуся в РНБ, но на первом видны печати библиотеки и указание на количество имеющихся гравюр в библиотеке («24 con la portada», т. е. «24, включая титульный лист»), а во втором от руки добавлен номер (1, справа от посвящения на латыни). 


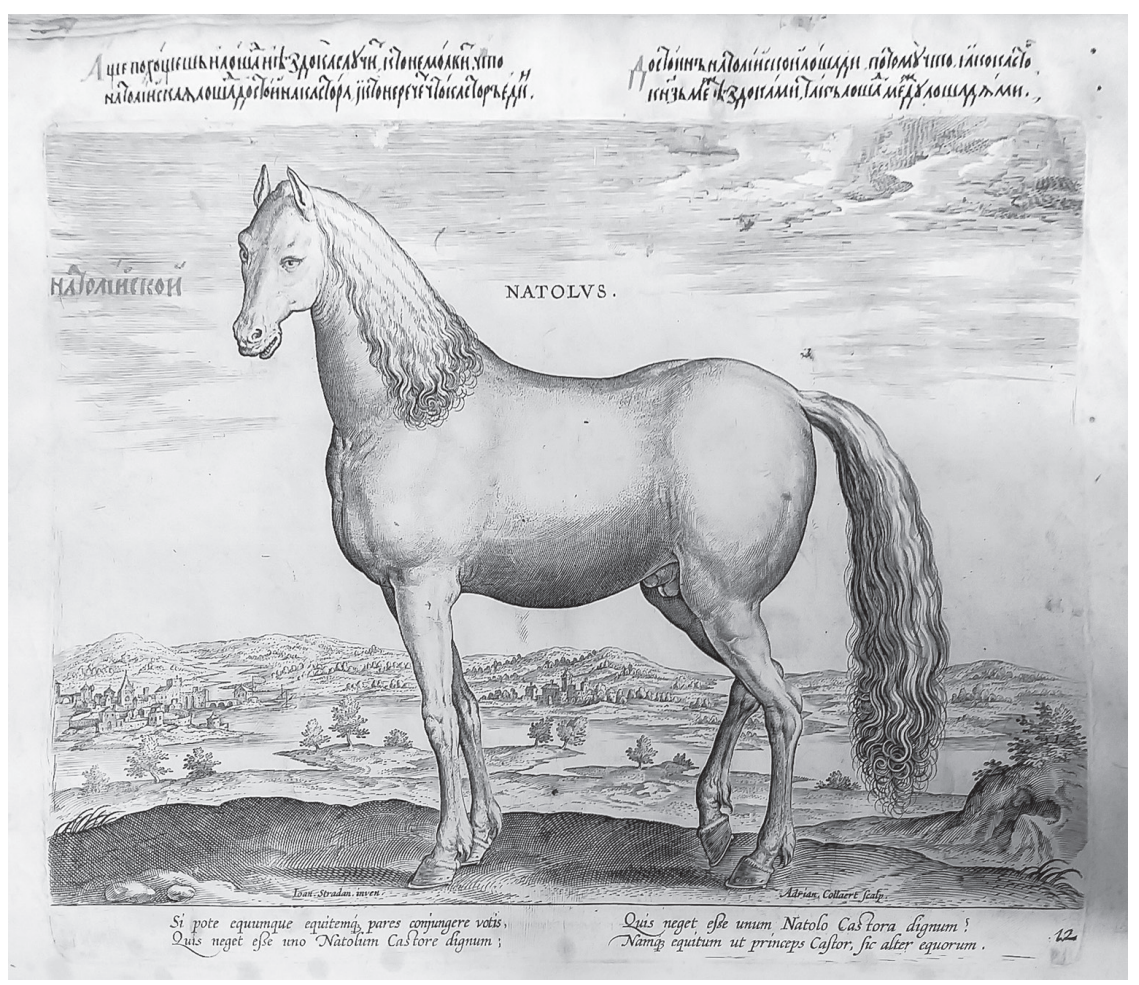

Илл. 2: «Natolus» (анатолийская лошадь), типичная гравюра из серии.

Русский перевод и цифра 12 справа от латинского стихотворения добавлены от руки.

В правом нижнем углу указан гравер титульной страницы - «Adrianus Collaert scalpsit ${ }^{8}$. Еще ниже, за пределами гравюры, имеется длинное посвящение на латыни господину Альфонсо Феличе д’Авалос (1564-1593) сле смерти Хуана Австрийского было неуместно (или, по крайней мере, невыгодно) посвящать гравюры ему, и Галле выбрал другого адресата, который в какой-то момент мог быть ему полезным.

На двух других гравюрах также фигурирует фамилия художника и гравера Адриана Колларта из Антверпена (ок. 1560-1618; например, «Natolus», см. илл. 2). А. Колларт - самый молодой из упомянутых граверов - явно был привлечен к работе над серией не с самого начала; он работал в мастерской Галле ок. 1580-1595 гг., в 1586 г. женился на дочери Филиппа Галле ${ }^{10}$. Целые 12 гравюр были изготовлены Иеронимом Вириксом (Hieronymus Wierix, 1553-1619), средним из братьев Вириксов, четыре - Генриком Гольциусом

8 В более поздних изданиях - sculpsit.

9 «Ill[ustrissi]mo et excell[entissi]mo D[omino] Alphonso Felici d'Avalos et Aragona, Marchioni del Vasto ac Pescara, Dvci montis D. Ioannis, Principi Francae=Villae, Eqviti avrei Velleris, Maiestati Catholicae à consiliis, eqvivumq[ue] pro eadem in Belgio Magistro Observantiae Monvmentvm Philippvs Gallaevs D[ono] D[edit]». Адресат посвящения, неаполитанский патриций Альфонсо Феличе д’Авалос, гранд Испании, несмотря на свою молодость, уже в момент составления текста для посвящения обладал целым рядом почетных титулов (в частности, он являлся рыцарем ордена Золотого руна).

10 См. [Sellink 2012: 116; 131, прим. 19]. 
(Hendrick Goltzius, 1558-1617), приобретшим всемирную известность ${ }^{11}$. Примерно одна треть листов осталась без указания гравера. Они были гравированы предположительно Гольциусом и Яном/Гансом Коллартом (младшим братом Адриана), а в нескольких случаях — анонимным членом мастерской Галле [NHD Stradanus: 232]. Когда упоминается художник, по рисункам которого изготовлялись гравюры, всегда указывается Страданус.

\section{Equile Ioannis Austriaci: издания, хранилища}

Первые издания фламандских гравюр вышли без указания места и года печати, но все библиографические описания сходятся в том, что они вышли в Антверпене, где жил и работал издатель первоначальной серии Филипп Галле (а потом его сын и внук). Таким образом, в идентификации места печати гравюр вряд ли стоит сомневаться. Что же касается датировки, то в этом вопросе библиотечные каталоги сильно расходятся. Так, например, электронная база данных «Verzeichnis der im deutschen Sprachbereich erschienenen Drucke des 16. Jahrhunderts (VD16)» указывает на 1578 г. (предположительно), а каталог Британского музея - 1578-1580 гг. В каталоге Государственного музея Нидерландов вся серия датируется «ок. 1578-1582», в то время как для индивидуальных гравюр порой указывается более поздний срок, а именно 15831587 гг. Искусствовед Лидтке пишет об их появлении в свет в 1581 г. [Liedtke 1989: 29]. Согласно престижному каталогу произведений Страдануса в серии «The New Hollstein», цикл был впервые напечатан ок. 1580 г. (без гравированной нумерации листов), а второй раз - с добавлением нумерации листов ок. 1585 г. [NHD Stradanus: 232]. Если говорить о состоянии медных досок, как это принято в искусствоведении, то наиболее древние оттиски отражают первое состояние (это самые ценные гравюры, сделанные со «свежих» досок), а более поздние - второе состояние, но оба состояния причисляются к первому изданию - изданию Филиппа Галле ${ }^{12}$. (Об изданиях его сына и внука, уже XVII века, см. ниже.)

Попытки датировать серию обычно не аргументируются. Исходя из того обстоятельства, что Иероним Вирикс большей частью сидел в тюрьме с октября 1578 г. по март 1580 г. [van Ruyven-Zeman 2004: XVI; XLIII, прим. 23], некоторые исследователи, очевидно, делают вывод о том, что после 1578 г. он

11 Мы не включаем в наш перечень анонимные гравюры, приписанные Вириксу или Гольциусу, так как атрибуции искусствоведов по этому поводу часто не совпадают. Например, американский издатель и искусствовед В. Л. Страус относит целых 15 гравюр из данного цикла к творчеству Гольциуса (см. [Strauss 1977: 185-193], с иллюстрациями), но его атрибуция в новейшей литературе нередко оспаривается. Для некоторых из них в каталоге [NHD Stradanus] указывается как предположительный гравер Ян/Ганс Колларт старший (например, № 559).

12 [NHD Stradanus] содержит изображения всех 40 листов первого издания Филиппа Галле (издание 1.1), титульный лист и 39 изображений лошадей. Отсутствует «Семейство кентавров», гравированное Яном/Гансом Коллартом-младшим не ранее 1585 г. [там же: 232] (в этом году Ян Колларт стал работать в мастерской Филиппа Галле). См. также изображения в [Strauss 1977: 187-193] с указанием состояний медных досок, с которых были сделаны оттиски: первого состояния или второго (I/II). Каталог [NHD Stradanus] для отдельных гравюр различает до четырех разных состояний, но до сих пор еще могут появляться новые, неизвестные ранее состояния. 
уже ничего не мог сделать (например, [Hirschmann 1921: 153]), хотя работал гравером до конца жизни. Очень редко в связи с датировкой серии упоминают о том обстоятельстве, что адресат посвящения, Альфонсо Феличе д’Авалос, который на титульном листе назван, в частности, «рыцарем ордена Золотого руна» (см. цитату в прим. 9), был пожалован в рыцари этого ордена только в 1586 г. [Leesberg 2012: 242]. Таким образом, титульный лист не мог быть гравирован раньше 1586 г. (конечно, он мог быть изготовлен позже всех остальных гравюр). Нам представляется, что весь цикл, включая титульный лист, не мог быть напечатан раньше 1586 г., хотя большинство медных досок, несомненно, к тому моменту уже были готовы и, возможно, оттиски с них уже продавались как отдельные листы или более компактные серии.

Об исключительной популярности цикла гравюр по рисункам Страдануса свидетельствует тот факт, что помимо оттисков, выпущенных самим Филиппом Галле, в XVII в. гравюры были заново изданы не раз в том же Антверпене. Медные доски остались во владении мастерской Галле до смерти Иоганна Галле (1600-1676), внука Филиппа. Сначала Теодор Галле (1571-1633), сын Филиппа, тоже выпустил цикл, незначительно переделав (например, титульный лист остался неизмененным). На нескольких гравюрах он убрал имя отца и заменил его своим именем, но далеко не всегда; он также ввел отличающуюся от издания Филиппа Галле (во втором состоянии медных досок, 1.2) нумерацию гравюр. Кроме того, Теодор усилил рамку вокруг гравюр. За счет добавления «Семейства кентавров», отсутствовавшего в издании 1.1 Филиппа Галле, цикл гравюр во время Теодора Галле, таким образом, состоял из 41 л. (включая титул).

Более серьезные изменения сделал сын Теодора Иоганн, чья серия вышла с новым титулом: «Equile, seu speculum equorum, in quo omnis generis generosissimorum equorum ex variis orbis partibus insignis delectus [...]». На этот раз Антверпен эксплицитно назван на титуле: «Antwerpiæ apud Ioannem Gallęum» ${ }^{13}$. Зато давно уже скончавшийся Дон Хуан Австрийский там больше не фигурирует ([Virtuelles Kupferstichkabinett] датирует это издание 1638-1677 гг.). Еще одно антверпенское издание вышло после 1677 г., все еще с тех же досок из мастерской Галле (издателем был Ж. Петерс / Jacques Peeters) [NHD Stradanus: 232].

Итак, налицо четыре антверпенских издания: 1-е - Филиппа Галле (различаются два состояния, обозначаемые здесь как 1.1 и 1.2); 2-е - Теодора Галле; 3-е - Иоганна Галле; 4-е - Ж. Петерса. Мы тщательно изучили все эти издания, чтобы определить, к какому изданию/состоянию медных досок относятся петербургские оттиски. Издание Петерса - это единственное из четырех антверпенских изданий, которое в принциие не может быть представлено в комплекте РНБ (по причинам хронологии), так как в начале марта 1677 г. в Москве уже приступили к работе над переводом (см. ниже).

13 Полный комплект имеется в Музее им. герцога Антона Ульриха в Брауншвейге (см. [Virtuelles Kupferstichkabinett]). 
Помимо антверпенских эстампов, в Венеции вышло издание, датируемое Государственным музеем Нидерландов «не раньше 1624 и не позже 1648 г.» ${ }^{14}$. Издателем заявлен Маркус (Марко) Саделер, который сделал все гравюры заново, довольно точно скопировав оригиналы. Его оттиски характеризуются тем, что изображения являются зеркальными по сравнению с оригиналами; кроме того, не все детали совпадают. Венецианское издание в комплекте РНБ не представлено.

Поскольку речь идет не о книге, а о цикле гравюр, не стоит удивляться тому обстоятельству, что сохранившиеся листы разбросаны по многим хранилищам мира ${ }^{15}$. Полного комплекта почти нигде не сохранилось (ср. упоминания хранилищ для каждой гравюры в каталоге [NHD Stradanus: 233-253]). К редким исключениям относится Национальная библиотека Франции (Bibliothèque nationale de France) в Париже. Возможно, там хранится даже больше одного полного комплекта (всего их там четыре, но кажется, что другие неполные). Мы смогли изучить один полный комплект (41 л.), так как он доступен в Интернете. Этот комплект очень важен в нашем контексте, поскольку имеет целый ряд общих черт с петербургским. Почти все оттиски относятся к изданию Филиппа Галле (второе состояние медных досок; [NHD Stradanus]).

Полный комплект издания Филиппа Галле можно составить и из коллекций, имеющихся ныне в библиотеке герцога Августа (Herzog August Bibliothek) в Вольфенбюттеле. Там в трех разных коллекциях имеется всего 90 гравюр, относящихся к антверпенскому изданию Филиппа Галле ${ }^{16}$. Согласно каталогу [NHD Stradanus], они отражают второе состояние медных досок.

Помимо названных двух хранилищ, в Париже и Вольфенбюттеле, нам не известны иные примеры наличия полного цикла изданий XVI в. Хотя в четыpex коллекциях Государственного музея Нидерландов в Амстердаме (Rijksmuseum) хранятся 50 гравюр из нашего цикла ${ }^{17}$, полный комплект составить из них невозможно: отсутствует марокканская лошадь, «Equus Maurus» ${ }^{18}$. Bce другие известные нам серии явно неполные: в Королевской библиотеке в Стокгольме и в Британском музее в Лондоне хранится по 33 листа из Equile Ioannis Austriaci ${ }^{19}$ (списки отличаются по составу), а в Национальной библио-

${ }^{14}$ Весь альбом (42 л., включая титульный) доступен онлайн. URL: http://hdl.handle.net/ 10934/RM0001.COLLECT.592281 (дата обращения 25.05.2020).

15 URL: https://gallica.bnf.fr/ark:/12148/btv1b8490137x (дата обращения 25.05.2020).

16 Все они доступны онлайн на электронном ресурсе [Virtuelles Kupferstichkabinett]. Из-за пандемии мы должны были отказаться от планировавшейся командировки в Вольфенбюттель и могли изучить только копии в Интернете.

17 URL: https://www.rijksmuseum.nl/ (дата обращения 01.05.2020). При поиске по названию «Equile Ioannis Austriaci» в результат почему-то также включается альбом из венецианского цикла «Eqvile» Марка Саделера (см. прим. 18) и даже изображение Святого Патрика. Только 50 из 52 результатов относятся к антверпенскому циклу Equile Ioannis Austriaci.

18 В амстердамском музее также хранится альбом с полным комплектом гравюр под названием «Eqvile» (без упоминания Хуана Австрийского), изданных в XVII в. Марком Саделером в Венеции (BI-1893-3601; зеркальные копии оригинальных антверпенских гравюр). В этом альбоме «Equus Maurus» присутствует.

19 Гравюры Британского музея тоже доступны в Интернете. URL: https://www.britishmuseum.org/collection/search?keyword=equile\&keyword=ioannis\&keyword=austriaci. За фотографии стокгольмских гравюр мы сердечно благодарим сотрудника Королевской библиотеки Патрика 
теке Испании в Мадриде - $24^{20}$, т. е. ровно столько же, сколько и в СанктПетербурге. Сохранившийся в РНБ набор Equile Ioannis Austriaci не отражен в библиотечном каталоге, так как эти листы входят в состав рукописного конволюта; тем самым экземпляры РНБ не отражены в каталоге [NHD Stradanus].

\section{Кто сочинил латинские четверостишия на гравюрах по рисункам Страдануса?}

На нижних полях всех гравюр, за исключением титульного листа, помещены выгравированные стихотворения на латинском языке. Каждое из них состоит из четырех гекзаметров, чаще всего описывающих особенности лошадей той или иной породы (или других животных, когда идет речь о муле и осле). В тех случаях, когда на гравюрах изображены группы лошадей, латинские четверостишия объясняют содержание этих гравюр. Гекзаметры четверостиший написаны на безупречном латинском языке. У автора большой словарный запас, он часто использует довольно редкие слова и выражения; кроме того, он обладает широкими знаниями географии, истории, греческой и латинской литератур. В случае с «кобылой, оплодотворенной Зефиром» (богом западного ветра), он не только знал «Георгики» Вергилия, но и, скорее всего, знал наизусть, так как он привел почти дословную цитату, только слегка изменив порядок слов и отдельные слова (предлоги), — примерно так, как люди нередко делают, цитируя стихи по памяти (хотя нельзя полностью исключить, что он мог также списать подходящий текст, вполне сознательно немного его переделав $)^{21}$. О том, что он так же хорошо знал поэзию Овидия, свидетельствуют его стихи о муле и осле (№ 37 в комплекте РНБ; см. подробнее ниже, сравнение латинских четверостиший с переводом). Кроме того, создается впечатление, что автор был знаком с произведениями латинского писателя конца IV века Вегеция (Flavius Vegetius Renatus), в частности с его книгой о ветеринарной медицине «Digesta Artis Mulomedicinae», в которой особенное внимание уделено лошадям, ослам и мулам.

В поисках автора латинских четверостиший мы вначале обратили внимание на испанского ученого-гуманиста Бенито Ариас Монтано (1527-1598) 22 , отправленного королем Филиппом II в Нидерланды в 1568 г. [Hänsel 1991: 25]. В Антверпене он близко сотрудничал и дружил с местными учеными и издателями, в том числе с известнейшим книгоиздателем Кристофом Плантином и издателем многочисленных циклов гравюр Филиппом Галле. В течение нескольких лет в первой половине 1570-х гг. в мастерской Галле появился целый ряд гравюр и гравированных серий (включавших, как правило, от шести до

Гранхольма (даже эта библиотека оказалась недоступной из-за новой чумы). Стокгольмские гравюры - как и петербургские - не отражены в каталоге [NHD Stradanus].

20 URL: http://bdh-rd.bne.es/viewer.vm?id=0000043254\&page=1 (дата обращения 01.05.2020).

21 См. Вергилий, Georgica 3,273-277. Изображение из Equile Ioannis Austriaci (выгравированное Иеронимом Вириксом) со слегка переделанными стихами Вергилия см. PURL: http:// diglib.hab.de?grafik=39-1-geom-2f-00090 (дата обращения 18.05.2020).

22 См. фундаментальную монографию [Hänsel 1991] с многочисленными иллюстрациями гравюрами фламандских мастеров с четверостишиями Ариаса Монтано. 
ста гравюр), для которых Ариас Монтано написал латинские стихи. Поскольку не было общепринятым указывать имя автора подписей на гравюрах, можно предположить, что Бенито Ариас мог выполнить и ряд других подписей, считающихся анонимными. Но он покинул Антверпен весной 1575 г., поехав в Рим [Hänsel 1991: 8], поэтому не является самым подходящим кандидатом на роль автора «лошадиных стихов», хотя Галле и Бенито Ариас поддерживали контакт и дальше. Нидерландский гуманист Гадрианус Юниус ${ }^{23}$ - уроженец Гарлема, как и сам Филипп Галле, — тоже порой сочинял стихи для гравюр Ф. Галле, но он умер в 1575 г. (напомним, что Дон Хуан Австрийский приехал в Антверпен в 1576 г. и только тогда, скорее всего, была начата серия лошадей из конюшни Дона Хуана).

Еще одним потенциальным автором латинских гекзаметров - как нам представляется, наиболее вероятным — является Корнелис Килиан (ок. 1530 1607), известный основатель нидерландской лексикографии ${ }^{24}$. В течение полувека он служил в издательстве Плантина в Антверпене, сначала наборщиком, а с 1565 г. официально корректором [van den Branden et al. 1978: 34-38]. Он известен также как переводчик и автор латинских стихов на гравюрах, изданных, в частности, и Филиппом Галле. Каталог его трудов содержит описание всех его подписанных произведений: рукописей, собственных и переведенных им работ, его вклада в творения других авторов, латинских стихотворений на отдельных гравюрах или в составе циклов. В нашем контексте особенно важен тот факт, что Килиан фигурирует как автор латинских стихотворений в целом ряде серий гравюр, изданных Филиппом Галле 25 . Поскольку такие стихотворения часто выходили без указания автора, Килиан мог сочинить также и стихи на гравюрах из Equile Ioannis Austriaci. У нас не было возможности провести стилистические и содержательные исследования его творчества, чтобы аргументировать эту гипотезу. Но по ряду причин Килиан нам представляется наиболее вероятным кандидатом на роль автора рассматриваемых четверостиший: он подходит по возрасту и общей эрудиции, прекрасно владеет латинским языком и умеет сочинять гекзаметры. Кроме того, очень хорошо документировано его тесное сотрудничество с издателем Филиппом Галле, и он заведомо сочинил стихи для других изданий Галле по рисункам Страдануса (см. прим. 25).

${ }^{23}$ Подробнее о Юстусе см. работу [van Miert 2011].

24 Его биографию и список работ см. в книге [van den Branden et al. 1978]. Там же имеется краткая английская версия биографии (с. 46).

25 Например, в следующих циклах (номера относятся к каталогу [van den Branden et al. 1978]): Circulus vicissitudinis rerum humanarum (8 гравюр; № 43); Icones illustrium feminarum Novi Testamenti (16 гравюр, № 45); Icones prophetarum Veteris Testamenti (27 гравюр по рисункам Страдануса, № 47); Prosopographia (44 гравюры, № 50); Septem planetae (8 гравюр по рисункам Страдануса, № 51); Solitudo, sive vitae foeminarum anachoritarum (25 гравю, № 52); Venationes ferarum, avium, piscium. Pugnae bestiariorum \& mutuae bestiarum (105 гравюр, № 53). 


\section{Петербургский комплект Equile Ioannis Austriaci: общие замечания}

Из 24 гравюр в Equile Ioannis Austriaci, хранящихся ныне в РНБ, согласно нашему анализу, подавляющее большинство — а именно 19 листов — относятся к изданию создателя мастерской Галле, Филиппа ${ }^{26}$, а пять гравюр отражают состояние медных досок после обработки его сына, Теодора Галле, т. е. эти оттиски сделаны в XVII в., примерно до 1637 года (в 1636 г. Т. Галле умер $)^{27}$. Следов издания Иоганна Галле нами не обнаружено.

Ниже, справа от латинских четверостиший, чернилами проставлены номера гравюр. Среди имен других граверов на десяти листах фигурирует И. Вирикс, на трех - Г. Гольциус, а на двух (на титульном листе и № 12) - А. Колларт. На девяти гравюрах информация о гравере отсутствует ${ }^{28}$.

Нами не найдено никаких документов о том, когда и каким образом сохранившийся в РНБ набор фламандских гравюр оказался в России. Из того обстоятельства, что русский перевод латинских четверостиший был выполнен одновременно с переводом книги Плювинеля L'Instruction du Roy, не вытекает, что оригинал книги Плювинеля и фламандские гравюры с изображениями лошадей были доставлены в Россию одновременно, но это не исключено (например, по указу царя). Разумеется, как книга Плювинеля, так и цикл антверпенских гравюр в принципе давно уже могли быть во владении царской семьи, ведь парижскому изданию книги 1629 г., которое легло в основу перевода, в 1677 г. было уже почти полвека, а фламандским гравюрам — почти век. (Издание гравюр Теодора Галле, к которому относятся пять листов петербургского комплекта, могло быть напечатано примерно одновременно с книгой Плювинеля.) Сам факт, что сохранившиеся в Санкт-Петербурге гравюры относятся

26 Сравнения были сделаны при помощи каталога [NHD Stradanus] и доступных в научной литературе и в Интернете изображений из других хранилищ. Приводим полный список: № 1 (титул), 6 (Appulus), 8 (Turcus), 10 (Thessalus), 11 (Armenius), 12 (Natolus), 13 (Albanus), 15 (Tuscus), 16 (Romanus), 17 (Calaber), 18 (Insuber, лошадь Северной Италии), 19 (Siculus), 20 (Sardonicus), 21 (Corsus), 23 (Brito), 24 (Flander), 28 (Saxo), 29 (Cimber, лошадь Северной Германии), 37 (Mula et Asinus). В каталоге [NHD Stradanus] соответствующие оттиски из парижского комплекта «Ке-3», большей частью в точности повторяющего петербургский, приписываются второму состоянию медных досок, т. е. изданию 1.2 Филиппа Галле (в каталоге обозначенному как «ІІ»). Мы сначала определили эти листы (в РНБ) как относящиеся к первому состоянию (1.1), но верно, что на некоторых листах в РНБ - как и в Национальной библиотеке Франции - видны следы бывшей гравированной нумерации Филиппа Галле (в его издании 1.2). Например, № 10, «Thessalus», в левом нижнем углу имеет отпечаток прежней цифры 9, а на № 19, «Siculus», был удален в том же месте номер 11. Приведем еще один пример: на оттиске из цикла РНБ «Mula et asinus» в левом нижнем углу слабо видны следы цифры 7, а в правом углу от руки написано «37». Точно те же исправления отмечены и в парижском комплекте Ke-3 (см. [NHD Stradanus: № 535/II; 537/II; 557-II]). Следы бывшей нумерации видны и на целом ряде других гравюр РНБ, но в большинстве случаев затруднительно сказать с уверенностью, какие именно цифры были удалены. В каталоге [NHD Stradanus] указаны все ныне удаленные номера.

27 № 5 (Regius), 9 (Achivus), 22 (Gallicus), 39, 40 (группы лошадей без названий). Первые четыре подписаны Теодором Галле, последний лист (40) можно узнать по характерной для обработки Теодора рамке вокруг всей гравюры.

28 № 8 (Turcus), 13 (Albanus), 18 (Insuber), 20 (Sardonicus), 21 (Corsus), 23 (Brito), 24 (Flander), 37 (Mula et asinus), 40 (борющиеся лошади). 
к разнылм изданиям - конца XVI в. и первой половины XVII в. соответственно - несколько сужает возможный период приобретения царским двором цикла гравюр. При этом нет оснований предполагать, что часть комплекта гравюр была куплена еще в XVI в., ведь совершенно ясно, что комплект некогда был полным, состоял из 41 л. Кроме того, исключительное сходство петербургского и парижского комплектов наводит на мысль, что оба были приобретены примерно в одно и то же время (рукописные цифры на обоих чаще всего проставлены одной и той же рукой), либо непосредственно в мастерской Галле, либо у одного и того же торговца ${ }^{29}$. С уверенностью можно сказать, что цифры, добавленные от руки, были написаны выходцем из Нидерландов, об этом недвусмысленно говорят хотя бы его пятерки и восьмерки ${ }^{30}$. Таким образом, наша первоначальная гипотеза о том, что нумерация в наборе была введена переводчиком, оказалась неверной. Впрочем, то обстоятельство, что проставленные от руки номера на оттисках XVI в. большей частью совпадают с нумерацией, введенной только Теодором Галле в XVII в., наводит на мысль о том, что в его мастерской уже существовала неофициальная нумерация гравюр, категорически отличавшаяся от нумерации в издании 1.2 Филиппа Галле. Создается впечатление, что в мастерской Галле напечатанные листы старого издания хранились вместе с более «свежими» оттисками.

От всех других известных нам комплектов Equile Ioannis Austriaci петербургский отличается тем, что имеющиеся на каждой гравюре (за исключением титульного листа) латинские стихотворения переведены на русский язык. Как правило, переводы занимают четыре строки, точно так же, как и латинские стихотворения (исключением является № 37, «Ишак и осел», см. нашу транскрипцию в приложении). Переводы написаны от руки и помещены прямо на оригиналах, на верхних полях листов, над изображениями лошадей. При этом для первой буквы каждой первой и третьей строки использованы золотые чернила. Такими же чернилами написаны и названия пород (опять за одним исключением: название «Албанский» на № 13 написано обычными черными чернилами - безусловно, по невнимательности писца). Когда латинское название помещено слева от головы лошади, русское написано справа от нее (см. илл. 2), и наоборот. Исключением и здесь является «Албанский», где русское название написано не справа или слева от латинского, а над ним. (Когда на гравюре изображены две лошади одной и той же масти - № 16: самец и самка масти «Romanus», — русские названия тоже проставлены над латинскими.)

Гравюры сгруппированы так (очевидно, Теодором Галле, а не русским переводчиком), что сначала идут изображения лошадей определенных пород, каждая порода по отдельности, а к концу - листы, строго говоря, не типич-

29 См. илл. 2 выше, с добавленным от руки номером.

30 Что касается «нидерландской» формы цифры 8 (см. особенно на № 18, «Insuber» и № 28, «Saxo», или те же в парижском комплекте Ke-3), то эта форма, по нашим наблюдениям, еще не вышла из употребления в Нидерландах. Зато такого начертания цифры 5, как в парижской и петербургской подборке оттисков, мы раньше не встречали; по сообщению М. Лесберх (электронное письмо, 25 мая 2020 г.), это старая нидерландская форма, которую легко можно перепутать с цифрой 4 (она похожа на букву $S$ рунического алфавита, 4). 


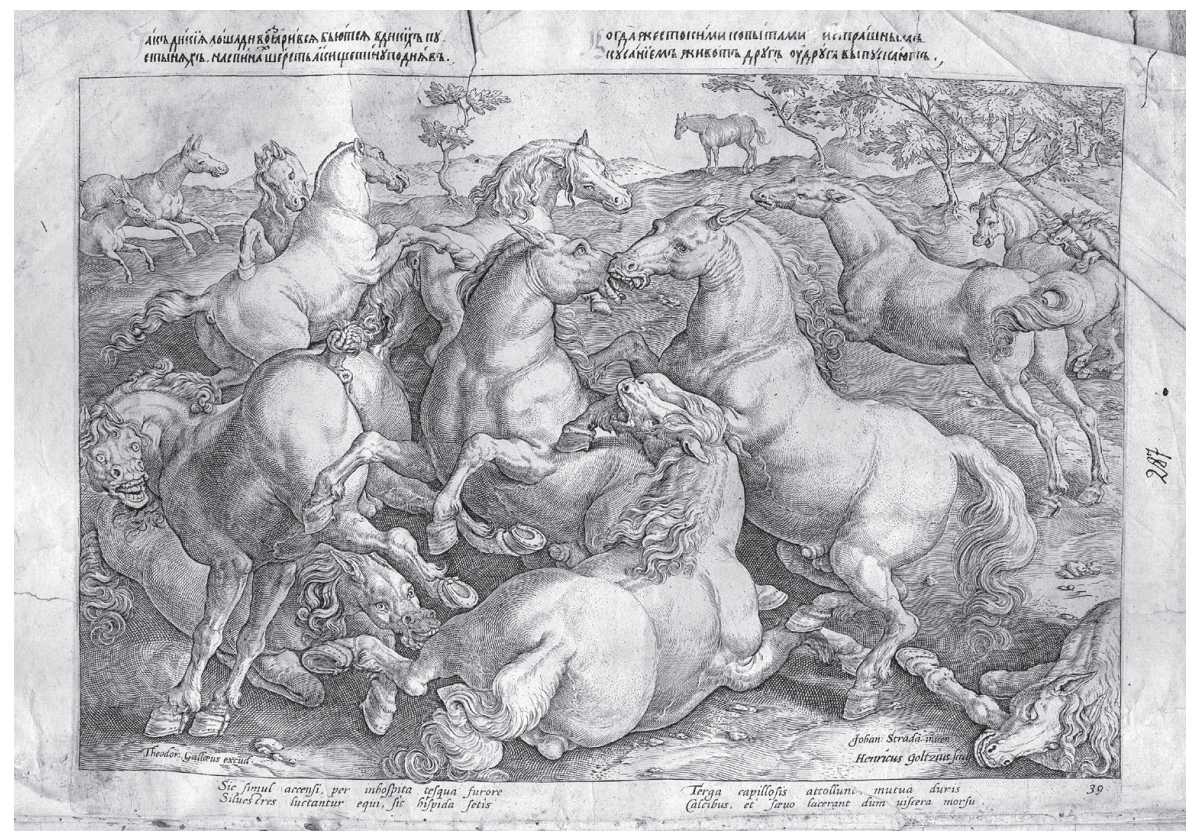

Илл. 3: Изображение группы лошадей из Equile Ioannis Austriaci (№ 39).

ные для цикла: с одной стороны, близкие родственники лошади (мул и осел, № 37), а с другой — целые групnы лошадей неопределенных пород (№ 39, 40). На № 39 (илл. 3) изображена большая группа лошадей, борющихся между собой, и дополнительно включены представители близких родственников, осел и мул. На № 40 можно видеть группу из шести борющихся между собой лошадей. При переплетении гравюра № 39 оказалась после № 40 (мы сохраняем этот порядок в нашем издании в приложении $)^{31}$. Основной порядок был уже задан приобретенным циклом, и на этом основании мы можем заполнить нынешние лакуны соответствующими изображениями (следуя нумерации на парижских гравюрах и учитывая недостающие в русской рукописной книге листы; см. список пропавших гравюр ниже).

Эти драгоценные гравюры сохранились под одним переплетом с переводом книги Антуана де Плювинеля L'Instruction du Roy .../ Reitkunst ... (начало русского перевода — «Учение, како об’езжати лошадей, се есть художество о яждении» ${ }^{32}$ ). Еще А. И. Соболевский совершенно верно указал на использование московскими переводчиками парижского оригинала 1629 г. [Соболевский 1903: 114]. Эта атрибуция далась ему легко, так как гравированный титульный лист парижского издания был вклеен непосредственно в русский

31 Существуют варианты этих гравюр с добавленными выгравированными заглавиями: «Рugna Equina» ('Борьба лошадей’ - 12 борющихся лошадей) на № 39 и «Libertas Equina» ('Свобода лошадей’ - шесть борющихся лошадей) на № 40. См. http://kk.haum-bs.de/?id=galle-t-exc-ab30040 и http://kk.haum-bs.de/?id=galle-t-exc-ab3-0039 (PURL).

32 Цитируется по единственному известному списку данного перевода (РНБ, Погод. 1717, л. 1 об.; это «заглавие» написано золотыми чернилами). Мы посвятили переводу 1677 г. книги Плювинеля отдельную небольшую статью [Майер 2021]. 
перевод. Ученый также справедливо определил, что «перевод сделан как будто с немецкого» [там же].

Исследователи-русисты до сих пор не уделяли особого внимания фламандским гравюрам с русскими переводами латинских стихотворений. Более того, ученые, как и подьячие XVII в., обычно рассматривали гравюры XVI в. с изображениями лошадей как составную часть книги Плювинеля, так как мало кто видел оригинал парижского издания Плювинелевой книги 1629 г. и знал, какие именно гравюры относятся к этой книге. Соболевский, правда, эксплицитно писал о том, что эти листы находятся «после сочинения Плювинеля» ([там же, прим. 2]; выделено нами. - И.М.). В то же время он ошибся, назвав Equile Ioannis Austriaci книгой, и эта ошибка до сих пор повторяется в научных работах ${ }^{33}$.

Сохранность всей рукописной книги на библиотечном «листе заверки» 1973 г. оценивалась как «плохая», с примечанием «переплет оборван, картон расклеивается, требуется реставрация» и подписью библиотекаря. С этой характеристикой, сделанной почти полвека назад, следует согласиться, но хочется добавить, что наиболее сильно пострадали листы начала и конца книги, а значит, как раз гравюры с изображениями лошадей из конюшни Хуана Австрийского. Помимо того, что особенно в этой части пропало большое количество листов ${ }^{34}$, иногда оторваны кусочки листов (что хорошо видно на илл. 3 ). Сравнительно плохое состояние последних листов рукописи, возможно, частично связано с тем, что их бумага тоньше и поэтому больше подвержена механическим повреждениям, чем более качественная бумага, на которой написан перевод книги Плювинеля.

\section{Датировка русского перевода}

С датировкой перевода как книги Плювинеля L'Instruction du Roy, так и латинских четверостиший нам - исследователям - сильно повезло. Очень редко встречаются случаи, когда документы Посольского приказа предоставляют такую подробную информацию об инициативе перевода, о переводчиках и о сроках их работы. С уверенностью можно сказать, что указ о переводе книги Плювинеля исходил лично от царя (Федора Алексеевича, годы правления 1676-1682), согласно документу из делопроизводства Посольского приказа: «великий государь» дал указ 9 марта 1677 г., чтобы «книга конского учения, которая от великого г(о) $c($ у)даря сверху снесена в Посолской приказ в декабрь м(е)c(я)це н(ы)нешняго году ${ }^{35}$ [была] отдана переводить переводчикомъ $[\ldots] »^{36}$ (л. 3; далее следует список группы переводчиков с распределением между ними конкретных листов).

33 Ср., например, [Назаренко 1956: 235]. Из работ последних лет можно назвать главным образом [Шапиро 2017], причем современная исследовательница явно не держала в руках петербургскую рукопись.

34 О них речь пойдет подробнее ниже.

35 Т. е. предыдущего года, согласно современному календарю.

36 РГАДА, ф. 159, оп. 2, ч. 1, ед. хран. 1735 (1677 г.), л. 1-4 (в дальнейшем ссылки на этот документ даются прямо в тексте, указывается только номер листа, в скобках). См. также [Лаврен- 
Таким образом, совершенно точно можно сказать, что перевод книги Плювинеля и латинских стихотворений на фламандских гравюрах был сделан в 1677 г. Эту дату можно даже уточнить: работа проводилась в промежутке между 9 марта и 11 ноября 1677 г. (т. е. чистовик обоих произведений был готов не позже 11 ноября). Согласно упомянутому царскому указу, перевод должен был быть готов гораздо раньше, к празднику Троицы, который в 1677 г. отмечался 3 июня. Выбор именно этой даты, очевидно, объясняется тем, что Троица связывалась с конем; например, в некоторых регионах России на Троицу был обычай «вождения коня» ${ }^{37}$. Однако план царя оказался слишком оптимистическим, и работа над переводом, составлением чистовика, подшивкой в готовую рукопись иллюстраций из оригинальной книги Плювинеля все-таки заняла значительно больше трех месяцев.

Перевод книги Плювинеля (с ее немецкой версии) выполнили переводчики Посольского приказа Андрей Виниус, Леонтий Гросс и Ефим Мейснер, а «подписи» под изображениями лошадей - т. е. стихотворения из цикла Equile Ioannis Austriaci - переводил Семен Лаврецкий (переводчик с польского и латинского языков): «А переводили тое книгу на словенской язык с немецкого писма Посол'ского приказу переводчики Андрей Виниюс, Леонтеи Гросъ, Ефимъ Мейснеръ. Латинские подписи, что у лошадеи, переводилъ Семенъ Лаврецкои» (л. 3). Очевидно, подьячие Посольского приказа не понимали, что гравюры из Equile Ioannis Austriaci не относятся к книге Плювинеля. Поскольку на гравюрах нет даты выпуска, а также и потому, что книга Плювинеля тоже изобилует гравюрами лошадей, это не так удивительно: подьячие приказа, конечно, не проводили исследования исходных материалов. Для нас важен факт, что книга Плювинеля и «подписи» под изображениями лошадей (т. е. стихи из Equile Ioannis Austriaci) переводились одновременно. Таким образом, указанные в процитированном документе сроки - с 9 марта до 11 ноября 1677 г. - относятся к переводу как книги, так и латинских четверостиший. Из документа Посольского приказа также вытекает, хотя бы косвенно, что два произведения о лошадях не только переводились, но также и переписывались набело одновременно, одним и тем же писцом. Дата выдачи камки (китайская узорчатая ткань типа дамаста) подьячему Максиму Бурцову за его работу, 11 ноября 1677 г., является крайней датой, когда беловик обоих произведений был закончен: «186-го [1677] ноября въ 11 де(нь) г(о)c(у)д(а)рь пожаловал, вельл ему дат своего г(о)c(у)д(а)рева жалованя камку за ево труды» (л. 4; эти строки добавлены внизу листа трудно разбираемым почерком). Кому была выдана камка и за какую работу, мы узнаем из того же документа. Данная информация расположена несколько выше на том же листе: «А выправливал тое кни-

тьев, Матвеева 1992: 242-243] с кратким пересказом содержания документа и [Майер 2021] с подробной дискуссией.

37 За эту информацию мы благодарны Олегу Русаковскому. См. [Виноградова, Плотникова 1995: 391]: «В некоторых ю.-рус. и поволжских областях “вождение коня” происходило на Троицу или на Русальной неделе». Таким образом, неверна информация в работах [Седов 1995: 82; 2006: 275] о том, что «К Троице 1677 г. Федору поднесли перевод французской книги Антония де Плувинелла [...]». (Подробнее о некоторых конкретных причинах для задержки см. [Майер 2021].) 
гу и над книгописцомъ смотрилъ и фигуры к’ речам прибиралъ и набело справливал Посолского приказу подячеи Максимъ Бурцов».

За какую именно работу Бурцову выделили камку? Видимо, он сначала правил черновые переводы переводчиков и собирал их вместе («выправливал»). Он также контролировал работу переписчика («над книгописцом смотрил»), занимался размещением иллюстраций («фигуры к речам прибирал» ${ }^{38}$ ) и наконец собирал и проверял окончательный результат («набело справливал»). Документ говорит об одном книгописце, что совпадает с нашим наблюдением: беловики перевода книги Плювинеля и латинских четверостиший написаны одной и той же рукой. Это обстоятельство объясняет, почему беловики переводов двух разных источников, объединенных на основе общей тематики, характеризуются рядом общих черт. Так, в роскошном беловом списке перевода книги Плювинеля все заглавия написаны золотыми чернилами, а на фламандских гравюрах точно так же «заглавия» (т. е. породы лошадей) написаны золотом. Кроме того, в переводе книги Плювинеля первые буквы каждого нового абзаца выделены золотом, а в переводе латинских стихотворений первая буква каждой первой и третьей строки выделена точно таким же образом (см. илл. 2 и 3 ).

\section{Пропавшие ныне гравюры в петербургском комплекте Equile Ioannis Austriaci}

В 1677 г., когда готовился перевод, цикл гравюр с лошадьми по рисункам Страдануса, очевидно, состоял из 41 листа. Об этом свидетельствует в первую очередь общая фолиация рукописной книги, причем нумерация гравюр (1-40 на сохранившихся ныне листах) соответствует кириллической фолиации, т. е. каждая лакуна в нумерации гравюр сопровождается лакуной в фолиации (например, нет гравюр № 2-4, и л. 276-278, где должны были быть эти гравюры, тоже отсутствуют). Остались только 24 листа, а значит, в настоящее время отсутствуют 17 листов. О том, что переводчику вручили именно 41 л., мы узнаем из документа Посольского приказа, из которого мы уже привели несколько цитат: в нем написано, что Семену Лаврецкому были выданы листы с 249 по 289 (л. 1), то есть 41 лист. Правда, информация о листах 249-289 выглядит несколько странно на фоне того, что такой нумерации с самого начала не было, - пронумерованы были только сами гравюры, № 1-40 (или, вероятнее всего, 1-41). Конечно, подьячий приказа мог обсчитаться, но между л. 287 (по библиотечной нумерации, без кириллической цифири) и задней переплетной крышкой явно был вырезан лист. Ввиду плохого состояния рукописной книги трудно сказать, что́ он собой представлял, — гравюру или переплетный лист. Если там была гравюра, это могла быть гравюра № 41 - «Семейство кентавров» ${ }^{39}$. Если же там был переплетный лист, позднее вырезанный по

38 Эта задача относилась исключительно к переводу книги Плювинеля, где действительно надо было подобрать иллюстрации из оригинальной книги и решить вопрос, где их поместить в переводе.

39 «Семейство кентавров» не входило в первоначальный цикл Филиппа Галле. Наверное, по 
какой-то причине (неизвестно, кем и когда), то гравюра № 41 могла оказаться между л. 311 и 314, так как в этом месте отсутствуют два листа, хотя согласно нумерации оттисков там должен был быть только № 38. Возможно, кентавры оказались в этой лакуне, ведь к концу цикла прямой порядок нумерации гравюр № 39 и 40 был нарушен (либо Бурцовым, либо переплетчиком) $)^{40}$. В таком случае последние три листа могли носить обратную нумерацию в комплекте РНБ: № 41, 40, 39. Этот порядок соответствовал бы возрастающему количеству лошадей (и кентавров): четыре кентавра (родители и двое детенышей-сосунов) - шесть борющихся лошадей - 12 борющихся лошадей (кроме того, сзади слева мул и осел подбегают к борющимся лошадям, правее центра пассивно стоит лошадь; см. илл. 3).

Опираясь на полный цикл гравюр в каждом антверпенском издании, мы можем составить перечень пропавших гравюр с указаниями в квадратных скобках их предположительных номеров (на основании серии из Национальной библиотеки Франции, Кe-3). Для изображений одной лошади с латинскими названиями на гравюрах мы даем эти названия; для других оттисков (групп лошадей, кентавров и т. д.), на которых нет названий, мы переводим на русский язык названия, данные этим гравюрам в разных каталогах. Эти названия всегда отражают текст латинского четверостишия, соответствующего им.

\section{Отдельные лошади}

$\begin{array}{lll}\text { [2] Neapolitanus } & \text { [3] Equus Hispanus } & \text { [4] Hispanus (Alter }{ }^{41} \text { ) } \\ \text { [7] Britannus }{ }^{42} & \text { [14] Dacus }{ }^{43} & \text { [25] } \text { Phryso }^{44} \\ \text { [26] Juliacus } & \text { [27] Equus Germanus } & \text { [30] Sicamber }\end{array}$

этой причине кентавры отсутствуют в каталоге [NHD Stradanus], отражающем серию главным образом в виде издания 1.1 Филиппа Галле и иллюстрирующем только первоначальные гравюры (титул +39 гравюр).

40 Не исключено, конечно, что подьячий - Максим Бурцов - просто в этом месте ошибся в фолиации, к самому концу книги.

41 На первоначальных медных досках Филиппа Галле слово Alter присутствовало, но позднее оно было соскоблено, поэтому мы его взяли в скобки. На парижском экземпляре хорошо видны следы удаления одного слова (название там просто Hispanus). Ясно, что парижский оттиск не отражает первое состояние гравюры.

42 Britannus в принципе может быть либо британская (английская) лошадь, либо бретонская, но, поскольку Brito явно относится к Англии, мы предполагаем, что Britannus относится к Бретани; ср. также [Ridgeway 1905: 324]: «Though the departments of Western France supply but few fine horses, yet Brittany from time immemorial has had an excellent breed, 'absolutely identical' with that of Morvan, Auvergne, and Ariège. The best French authorities maintain that the Breton horses are 'Asiatic', i.e. Libyan, in origin.»

43 Лат. Dacia, Дакия, часть современной Румынии.

44 Ср. характеристику английского автора XVI в. [Blundeville 1560], ссылавшегося на римского ипполога Вегеция (IV в. н. э.): «And Vegetius saith that the Frizeland Horses be verie swift in running, and able to maintaine a long course. And indeed I have seene of them myself, that would make a good cariere and manege verie weill, and also do the curvet so trulie as anie jennet of Spain» (цит. по книге [Ridgeway 1905: 340]).

45 Cp. [Ridgeway 1905: 338]: «Under the names of Sicamber and Juliacus two horses almost identical with the High Almain [= German. — I.M.] and Flanders breeds are given by Stradanus [...]» (Sicambri жили в районе немецкого города Клеве, Juliacus относится к бывшему графству Юлих; в настоящее время оба района расположены в федеральной земле Северный Рейн - Вестфалия). 
[31] Danus [32] Equus Maurus ${ }^{46} \quad$ [33] $\mathrm{Afer}^{47}$

[34] Equus liber et incompositus

\section{Группы лошадей}

[35] Liberi Equi Cursitatio

[38] Duellum Equinum

\section{Мифологические лошади/кентавры:}

[36] Кобыла, оплодотворенная Зефиром ${ }^{48}$

[41] Семейство кентавров

Подведем некоторые итоги. Из комплекта, который дали Лаврецкому в 1677 г. для перевода, позднее были извлечены 12 гравюр с отдельными лошадьми определенных пород (помимо пяти других гравюр, на которых были, например, изображения групп коней и кентавры), причем исключительно выдающихся, давно известных пород, например, две испанские лошади, которых очень высоко ценили, так как в них много арабской крови ${ }^{49}$. Изображения самих арабских пород тоже были удалены: марокканская лошадь (Maurus) и берберская (Afer), а еще неаполитанская и целый ряд популярных североевропейских пород. При этом бросается в глаза, что многие из отсутствующих ныне гравюр показывают лошадей, поднявшихся на дыбы, например, обоих представителей испанской породы (одна смотрит вправо, вторая - влево ${ }^{50}$ ). В такой же позе - популярной и для скульптур - изображены датская лошадь, неаполитанская и «свободная неукрощенная лошадь» ${ }^{51}$ (последняя позиция в списке «Отдельные лошади», в исполнении самого известного гравера, участвовавшего в создании цикла, - Генрика Гольциуса). Из оттисков, на которых изображены группы лошадей, «бьющиеся на поединке лошади» («Duellum equinum») тоже поднялись на дыбы ${ }^{52}$, а гравюра с марокканской и берберской лошадьми очень похожи на изображения лошадей, вставших на дыбы: на них изображены галопирующие лошади. (Марокканская лошадь, кстати, во всем цикле является единственной с ездоком.) Не исключено, конечно, что художник Страданус сознательно нарисовал лошадей самых известных пород именно в подобной позиции - либо на дыбах, либо в галопе. Напрашивается вывод о том, что человек, удаливший отдельные гравюры (больше трети, но

46 Марокканская лошадь, см. [Ridgeway 1905: 242].

47 Берберская лошадь, см. [Ridgeway 1905: 241].

48 Зефир - бог западного ветра.

49 Ср. описание испанской лошади из английской книги о коневодстве 1560 г. (Thomas Blundeville; цит. по [Ridgeway 1905: 259]): "The Jennet of Spaine is finelie made, both head, bodie, and legs, and very seemlie to the eie, saving that his buttocks be somewhat slender, and for his fine making, lightnesse, an swiftnesse withal, he is verie much esteemed, and especialie of noble men, as Camerarius saith, which Oppianus also affirmeth, saieng: that the Jennet in swiftness passeth the Paerthians and all other horses whatsoever they be, even so far as the Egle exceedeth all the birds in the aire, and as the Dolphin passeth all the fishes in the sea [...]". Тут английский ипполог XVI в. ссылается, в частности, на Оппиана (Оллtavós). В другом месте он цитирует византийского автора Апсирта

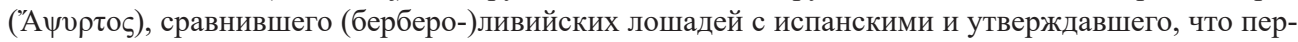
вые "be of like goodness, and of like shape to the Spanish, save that the Libyans be stronger made, longer bodied, thicker ribbed, and broader breasted" [там же: 258].

50 Equus Hispanus (PURL: http://diglib.hab.de?grafik=39-1-geom-2f-00056); Hispanus (PURL: http://diglib.hab.de?grafik=graph-a1-834i).

51 PURL, в этой последовательности: http:/diglib.hab.de?grafik=graph-a1-834m; http:/diglib.hab. de?grafik=graph-a1-783mm; http://diglib.hab.de?grafik=graph-a1-834e (дата обращения 25.05.2020).

52 PURL: http://diglib.hab.de?grafik=graph-a1-2813d (дата обращения 25.05.2020). 
меньше половины всей серии), прекрасно знал, какие лошади больше всего ценятся.

Петербургский комплект Equile Ioannis Austriaci в принципе относился к первому изданию цикла из мастерской Филиппа Галле, но ко второму состоянию медных досок (1.2), где на отдельных листах имелась гравированная нумерация листов. Но эти номера были удалены и заменены совсем другой нумерацией, сделанной от руки. Это было сделано, скорее всего, в мастерской Теодора Галле где-то в первой трети XVII в. или в любом случае до приобретения гравюр московским двором.

\section{Кто удалил гравюры из рукописной книги?}

Отсутствующие ныне гравюры, очевидно, пропали еще до конца XIX века: в соответствии с листом проверки 1898 г. рукопись состояла из 288 л. ${ }^{53}$ (в марте 1907 г. считали 287 л.). Согласно кириллической же нумерации количество листов было как минимум $315^{54}$. Получается, что по сравнению с первичной - кириллической - нумерацией в настоящий момент отсутствует не меньше 27 листов - то есть даже больше, чем 17 извлеченных листов из Equile Ioannis Austriaci. Впрочем, уже к концу перевода книги Плювинеля разница между двумя фолиациями (кириллицей, с одной стороны, и арабскими цифрами - с другой) составляет 11 л. При этом современная фолиация в переводе книги Плювинеля проставлена только на каждом десятом листе. Получается, что наш коллекционер гравюр (с изображениями коней) удалил также кое-какие из вклеенных в перевод Плювинеля иллюстраций (тоже гравированных), взятых непосредственно из оригинальной книги ${ }^{55}$. Представляется маловероятным, чтобы кто-то из читателей XVIII-XIX вв. удалил ценные гравюры, но это вполне мог себе позволить сам владелец гравюр и инициатор переводов, царь Федор Алексеевич. Доказать это невозможно, но широко известно, что у молодого царя был жгучий интерес к верховой езде и к лошадям известных пород. Согласно словам П. В. Седова, глубоко изучившего время правления царя Федора, «[у]влечение лошадьми Федор Алексеевич сохранил до конца жизни» [Седов 1995: 82]. Если молодому царю хотелось украсить, например, стены своей спальни картинками красивых лошадей, исследователям-искусствоведам с этим нужно примириться.

53 В это количество, вероятно, входил форзац, который библиотечной фолиацией (проставленной, видимо, в начале XX в.) не был учтен. Вычеркнутый номер л. 288 проверки конца XIX в. еще можно прочитать в правом верхнем углу гравюры № 39 (см. илл. 3).

54 Поскольку кусок бумаги на № 39, где должна была быть кириллическая цифирь, оторван (см. илл. 3), мы не можем сказать с уверенностью, какой на нем был номер, - скорее всего, 315. Л. 312-313 отсутствуют (на них, наверное, были гравюры «Поединок лошадей» и «Семейство кентавров»). На предпоследнем листе, «Шесть борющихся лошадей», читается «ТД» (очевидно, вместо «ТДІ» - 314; часть угла оторвана). Последним с полной кириллической цифирью является л. 311 (на котором читается «TAI»; № 37, «Mula et asinus»).

55 Например, между л. 30 и л. 33 (кириллицей) отсутствуют два листа — явно вклеенная в книгу иллюстрация, сложенная вдвое, состоящая из двух листов, так как большинство гравюр из книги Плювинеля имеют очень большой формат (сами гравюры ок. 212 х 302 мм, целый лист ок. 330 х 410 мм). Очень важно всегда иметь в виду, что лакуны уже имелись, когда была введена современная библиотечная фолиация. 


\section{Несколько слов о соотношении латинских гекзаметров с их русским переводом}

Переводчику - Семену Лаврецкому - выпала непростая задача: перевести гекзаметры на гравюрах XVI в. по рисункам Страдануса, сочиненные необыкновенно эрудированным автором-латинистом. Когда современные исследователи пишут, что Лаврецкий «ограничился переводом подписей под иллюстрациями» [Лаврентьев, Матвеева 1992: 242], они, наверное, себе представляют подписи типа «Lvdovicvs XIII Cristianissimvs Rex Franciae et Navarrae» на иллюстрациях в книге Плювинеля ${ }^{56}$. Но сверхкороткие объяснения на иллюстрациях в этой книге вовсе не были переведены (ни на немецкий, ни на русский), а на самом деле Лаврецкому нужно было перевести не меньше 160 стихотворных строк $(40 \times 4)$. Таким образом, доля работы Лаврецкого была не такой уж маленькой и, кроме того, довольно сложной, так как стихи на фламандских гравюрах XVI в. содержали немало специальных терминов, трудных географических названий и элементов из древнегреческой и классической латинской литературы. Он также должен был решить вопрос, как перевести: пытаться создать русские стихотворные тексты, подражая оригиналу, или, скорее, стремиться к прямой передаче смысла, пользуясь прозаическим языком?

В нашей небольшой статье нет места подробному анализу качества работы переводчика. Этой теме без труда можно посвятить целую статью. Здесь ограничимся лишь несколькими общими наблюдениями, в надежде на то, что ктонибудь из русских латинистов захочет взяться за более глубокий филологический анализ перевода.

Начнем с того, что, по нашему мнению, большинство четверостиший переведены довольно хорошо или даже отлично. Безупречно переведены, как нам кажется, стихи под гравюрами № 9, 11, 12, 20, 21, 22, 24, 28, 29, 39, 40 (см. издание ниже). При этом переводчик явно пытался передавать латинские четверостишия русскими строками примерно равной длины, возможно, в попытке подражать тем самым автору латинского оригинала. (Хотя, конечно, неизвестно, до какой степени переписчик вмешивался в структурирование текстов: например, кто ввел перенос слогов в № 39 и 40 - Лаврецкий или писец?) Иногда создается впечатление, что переводчик стремился к созданию рифмы; ср., например, № 28:

Нелегко ступаетъ, и голени отметываетъ. / И некрђпкого мастера долой збиваетъ. / И жестокое поломя из ноздрей изпускаетъ. смълъ ${ }^{57}$. / Высокъ. тушею и крестцомъ толсть.

Но это спонтанные и, скорее всего, случайные рифмы, состоящие из глагольных форм настоящего времени в третьем лице: отметываетъ, збиваетъ,

56 Цитируется по парижскому изданию книги L'Instruction du Roy (1629 г.). Лист с портретом молодого короля, с указанием «1624 г.», был вклеен в русский перевод (л. 5).

57 В латинском оригинале соответствие слову смғль - audax - относится к последней строке. Вполне возможно, что так и было в черновике Лаврецкого, но писец не любил, чтобы первая строка (или третья) была гораздо длиннее второй (четвертой). 
изпускаетъ. Изредка у Лаврецкого встречаются и другие рифмы, например (№ 6):

Зри возносящу свирђпое лице к небу: на задних опершуся /

Ногахъ, передними высоко к’ скоку воздвигнувшуся.

Но и здесь созвучие, возможно, возникает самопроизвольно. Более искусной рифмы в переводе Лаврецкого не обнаружено. Кроме того, его строки неравносложные, и в итоге нельзя сказать, что он стремился к стихосложению. Представляется более вероятным, что он просто добивался передачи смысла каждой строки оригинальных четверостиший.

С другой стороны, во многих случаях переводчик показывал свою эрудицию, например в связи с анатолийской лошадью (в РНБ - № 12; см. илл. 2 и нашу транскрипцию в приложении). Мы не уверены, что ему было известно именно то место в «Илиаде» Гомера (3.237), где идет речь о близнецах Касторе и Полидевке (лат. Pollux) - о так называемых Диоскурах — и где Кастор на-

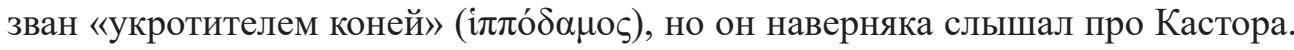
Все четверостишие, по нашему мнению, переведено самым лучшим образом.

Приведем также примеры менее удачных переводов. Тут в первую очередь следует назвать стихи о муле и осле (№ 37). Это и единственный случай, где переводчик явно отказался от перевода всего латинского четверостишия, написав только одну-единственную строку ${ }^{58}$, - правда, передающую (хотя с ошибками) первые две строки латинского стихотворения:

Лат. Mularum partus quod prodigiosus habetur, Frigida pigrities causa est, et inepta libido. Ipse Deo hortorum merito mactatur Asellus, Gaudia rugitu sua quod detexerit atro.

Рус. Рождение чюдно бываеть, виною есть озяблая льность, и похоть неугодна.

Переводчик явно не понял, о чем тут речь: чье рождение бывает чудным? Слово partus не обозначает '(пассивное) рождение', а скорее 'роды', ведь мулы, несомненно, рождаются, и в этом нет никакого чуда. Однако латинский автор хотел сказать, что мулица (самка мула) не может иметь потомства, а если это все-таки случается, то является prodigium, '(плохим) предзнаменованием'59. Причину этого автор видит в том, что мулица ленива и лишена сексуального желания. От перевода же последних двух строк Лаврецкий просто отказался (в нашем переводе: «Богу садов справедливо приносят в жертву самого осла, так как он [осел] разоблачил его [бога] радости роковым рычанием»). Переводчик наверняка не понял, что под выражением Deus hortorum имелся в виду Приап, и не знал, что, согласно рассказу Овидия, Приап нена-

58 Нельзя, конечно, утверждать с уверенностью, что писец беловика в этом отношении точно следовал черновику переводчика.

59 Ср. латинское крылатое выражение cum mula peperit 'когда рак на горе свистнет' (дословно ‘когда мулица рожает’), известное с I-II вв. нашей эры (Gaius Suetonius Tranquillus, Galba 4.2). Из этого вытекает, что еще в древности знали о бесплодии мулов. 
видел ослов, потому что, когда он собирался обесчестить спящую нимфу Лотис («радости» в четверостишии), вдруг громко закричал осел, так что Лотис и все присутствующие боги сразу проснулись и засмеялись над Приапом, который в ярости убил провинившегося осла ${ }^{60}$. Приапу приносили в жертву ослов, особенно в Лампсаке, центре культа Приапа. Но это, пожалуй, единственный раз, когда результат работы Лаврецкого должен получить самую низкую оценку. Впрочем, в то время как у современного исследователя есть возможность легко выяснить эту информацию, Лаврецкому она не давалась так просто. Да и сроки, вероятно, у него были еще более сжатые, чем у современных исследователей (в частности, у автора этих строк), и гравюра № 37 относилась к последним листам серии.

Итак, перевод № 37 - это абсолютное фиаско; читатель не получает даже приблизительного представления о содержании стихотворения. Таких случаев больше нет, но можно назвать еще ряд более мелких ошибок, причем наш список никак не претендует на полноту. Например, переводчик ошибается, назвав Апулию «королевством» (№ 6; лат. - Appula regna), ведь Апулийского королевства никогда не было: Апулия относилась к Неаполитанскому королевству (которое, однако, в период 1503-1734 гг. тоже не было независимым государством). В № 15 переводчик, очевидно, не понял, что под выражением solido cornu в данном случае не имеется в виду 'рог', а здесь идет речь о другом рогообразном предмете, копыте (первоначальное значение лат. слова cornu - 'рог'; отсюда в русской версии крепкою головою, вместо, к примеру, «крепким копытом / крепкой ногой»; зато в № 18 совершенно правильно переведено слово cornipedes, «рогатоногих»). В № 19 переводчик не понял выражения flavae parenti (имеется в виду Церера, богиня плодородия); он просто выпустил это выражение. Он не понял и того, что Сицилия - треугольный остров, поэтому омывается морем с трех сторон; в его версии получается «трема городами». Там же еще другие недоразумения: речь вовсе не идет о войнах с какими-то «кикропийскими народы», а латинский автор говорит о том, что ездок на сицилийской лошади, отправлявшийся на соревнования в Афины, часто становился победителем.

Ограничимся этими немногими примерами, хотя при желании можно добавить еще ряд как отличных, так и менее удачных решений. Однако хотелось бы еще раз повторить нашу общую оценку: переводчик в основном понимал сложные латинские поэтические тексты и сумел их большей частью правильно передать по-русски.

\section{ЛИТЕРАТУРА}

Виноградова Л. Н., Плотникова А. А. Водить, вождение // Славянские древности: Этнолингвистический словарь в пяти томах. Т. 1: А (Август) - Г (Гусь) / под ред. Н. И. Толстого. М.: Международные отношения, 1995. С. 390-392.

Лаврентьев А. В., Матвеева Е. Н. Гросс Леонтий // Словарь книжников и книжности Древней Руси. Вып. 3. Ч. 1. СПб., 1992. С. 241-244.

${ }^{60}$ Cм. Ovidius, Fasti 1, 415-440. 
Maйер И. Русский перевод книги Антуана де Плювинеля L'Instruction du Roy / Reitkunst с немецкого языка. 2021 (в печати).

Назаренко И. И. Некоторые рукописные источники по зоотехнии XVII-XVIII веков // Вопросы истории естествознания и техники. М.: Изд. Академии наук СССР. 1956. № 1. С. 235-241.

Седов П. В. Детские годы царя Федора Алексеевича // Средневековая Русь. Сборник научных статей к 65-летию со дня рождения профессора Р. Г. Скрынникова / сост. С. В. Лобачёв, А. С. Лавров. СПб.: Издательство Санкт-Петербургского университета, 1995. С. 77-93.

Седов П. В. Закат Московского царства. Царский двор конца XVII века. СПб.: «Дмитрий Буланин», 2006. $604 \mathrm{c.}$

Соболевский А. И. Переводная литература Московской Руси XIV-XVII веков. Библиографические материалы. СПб.: Типография Императорской академии наук, 1903. 460 с.

Шапиро Б. Л. Царские библиотеки XVII в.: книги «лошадиного учения» // Литература в системе культуры. К семидесятилетию профессора И. В. Кондакова: сб. статей по итогам Международной научно-практической конференции. Москва, 15 апреля 2017 / Мин-во образования Московской области; Академия социального управления; сост. А. С. Баранов, А. В. Мартынов. М.: АСОУ, 2017. С. 112-118.

Baroni A. Johannes Stradanus. Biography // Stradanus 1523-1605. Court Artist of the Medici / ed. by A. Baroni and M. Sellink. Turnhout: Brepols Publishers n.v., 2012. Pp. 5-7.

Blundeville Th. The Arte of Ryding and Breakinge Greate Horses. London (1560). Amsterdam, New York: Da Capo Press (The English Experience. Its Record in Early Printed Books Published in Facsimile; 118), 1969. 178 pp. [+ 51 ill.].

van den Branden L., Cockx-Indestege E., Sillis F. Bio-bibliografie van Cornelis Kiliaan. Nieukoop: B. de Graaf, 1978. 232 p.

Hirschmann O. Verzeichnis des graphischen Werks von Hendrick Goltzius, 1558-1617 / Mit Benutzung der durch E. W. Moes hinterlassenen Notizen zusammengestellt von Otto Hirschmann. Leipzig: Klinkhardt \& Biermann, 1921. $174 \mathrm{~S}$.

Hänsel S. Der spanische Humanist Benito Arias Montano (1527-1598) und die Kunst. Münster: Aschendorffsche Verlagsbuchhandlung, 1991. 220 S. [+ ca. 200 S. Ill.].

Janssens S. The Flemish Roots of Johannes Stradanus // Stradanus 1523-1605. Court Artist of the Medici / ed. by A. Baroni and M. Sellink. Turnhout: Brepols Publishers n.v., 2012. Pp. 9-29.

Leesberg M. Equile Ioannis Austriaci Caroli V. Imp. F. // Stradanus 1523-1605. Court Artist of the Medici / ed. by A. Baroni and M. Sellink. Turnhout: Brepols Publishers n.v., 2012. Pp. 239-244.

Liedtke W. The Royal Horse and Rider: Painting, Sculpture, and Horsemanship, 1500-1800. New York: Abaris Books, 1989. 336 pp.

van Miert D. Introduction: Hadrianus Junius and Northern Dutch Humanism // The Kaleidoscopic Scholarship of Hadrianus Junius (1511-1575). Northern Humanism at the Dawn of the Dutch Golden Age / ed. by D. van Miert. Leiden: Brill Academic Publishers, 2011. Pp. 1-15.

van Miert D. Hadrianus Junius (1511-1575). Een humanist uit Hoorn. Hoorn: Vereniging Oud Hoorn, 2011. $160 \mathrm{p}$.

NHD Stradanus - The New Hollstein Dutch \& Flemish Etchings, Engravings and Woodcuts / [19] Johannes Stradanus. Part 3 / Compiled by M. Leesberg, ed. by H. Leeflang. Ouderkerk aan den Ijssel: Sound \& Vision Publishers, 2008. 319 pp. [+ ill.].

Oxford Art Online [Электронный pecypc]. URL: https://www-oxfordartonline-com (дата обращения 07.05.2020).

Ridgeway $W$. The Origin and Influence of the Thoroughbred Horse. Cambridge: University Press, 1905. $538 \mathrm{pp}$.

van Ruyven-Zeman Zs. Introduction // Hollstein's Dutch \& Flemish Etchings, Engravings and Woodcuts. Vol. 69. The Wierix Family. Introduction and Guide to the Catalogue / ed. by J. van der Stock, M. Leesberg. Rotterdam: Sound \& Vision Publishers, 2004. Pp. XII-XLV.

Sellink M. Introduction // The New Hollstein Dutch \& Flemish Etchings, Engravings and Woodcuts. Philips Galle. Part 1 / ed. by M. Sellink. Rotterdam: Sound \& Vision Publishers, 2001. Pp. XXXIVLXXXI.

Sellink M. Johannes Stradanus and Philips Galle: A Noteworthy Collaboration between Antwerp and Florence // Stradanus 1523-1605. Court Artist of the Medici / ed. by A. Baroni and M. Sellink. Turnhout: Brepols Publishers n.v., 2012. Pp. 109-133. 
Strauss W. L. Hendrik Goltzius, 1558-1617: the Complete Engravings and Woodcuts / ed. by W. L. Strauss. 2 vols. New York: Abaris books, 1977. 792 p.

VD16 - Verzeichnis der im deutschen Sprachbereich erschienenen Drucke des 16. Jahrhunderts [Электронный ресурc]. URL: http://www.vd16.de (дата обращения 01.05.2020).

Virtuelles Kupferstichkabinett [Электронный pecypc]. URL: http://www.virtuelles-kupferstichkabinett. $\mathrm{de} / \mathrm{de} /$ (дата обращения 01.05.2020).

ПРИЛОЖЕНИЕ

\section{Издание латинских стихотворений и русских переводов}

В передаче латинских названий лошадей и стихотворений за редкими исключениями сохраняется орфография оригинала. Буквы $u / v$ и $i / j$ пишутся строго в соответствии с оригиналом, т. е. во многих случаях $u$ следует читать как согласный $v$ (например, paruis читается как parvis) ${ }^{61}$. Букву $\beta$ читаем как ss (paßim $\rightarrow$ passim). Латинская буква «е caudata» (е)), замещающая сочетание букв ае или ое, пишется согласно оригиналу; например, pręscia venturę следует читать как praescia venturae. Лигатура $c$ сохраняется. Сокращения раскрываются в квадратных скобках, например: atq. $\rightarrow$ atq[ue]; recūbit $\rightarrow$ recu[m]bit. Разные формы буквы $<\mathrm{s}>\left(\mathrm{s}, \int, \int\right)$ не различаются. Если гравер перепутал буквы или сам автор допустил ошибку, мы даем исправленные написания в примечаниях.

Русские переводы даются в несколько упрощенной орфографии (как и цитаты из РГАДА, приведенные выше). Буква «ять» сохраняется, а остальные вышедшие из современного употребления буквы (диграф «оу», «ук», «юс малый», «і» ...) заменяются современными графемами $y, я, u$ и т. д. Выносные буквы вносятся в строку и выделяются курсивом. Знаки ударения опускаются, из надстрочных знаков воспроизводится только паерок (в виде апострофа, «'»). Пунктуация оригинала сохраняется, за исключением тех случаев, когда писец дает целый ряд знаков (типа «. - . - .») и когда точка в конце строки разрывает одно словосочетание (например, «на задних опершуся. / ногахъ» в № 6) $)^{62}$. Личные имена и географические названия пишутся с заглавной буквы, а также начальная буква каждой строки (за исключением переносов в № 40 и 39). Буквы, написанные золотом, не выделяются, сокращения типа «гсдрство» не раскрываются.

61 В гравированном тексте $u / v$ употребляются несистематично: в словах, написанных заглавными буквами, только $V$, а при строчном оформлении - преимущественно $u$.

62 У писца, очевидно, был принцип заканчивать каждую строку точкой - наверное, для красоты, но этот прагматический принцип сильно мешает чтению и пониманию. Что касается использования целого ряда пунктуационных знаков в конце строки, то в этом, наверное, заключается эстетический способ писца, стремившегося к тому, чтобы строки в одном и том же «двустишии» были одинаковой длины. Когда же первая строка была длиннее второй, он продлевал вторую, добавив разные знаки пунктуации, например точки и длинные горизонтальные черты, чтобы строки получились примерно одинаковыми (ср. особенно гравюру № 10, «Фессалийский», л. 284 в сборнике РНБ). 


\section{5. (279) Eqvvs regivs}

Ecce hic magnanimo qui conspicit, æthera vultu,

Hinnitusque ciet, corpusque oculosque superbus.

Regali fastum didicit nutritus in aula,

Aptus et ad pompam, et validis accommodus ausis.

\section{Королев'ская}

Се здъ великодушнымъ взоромъ смотрит кверху.

Ржетъ: теломъ ночьми доброзраченъ.

В королевском воспитана дворђ научилась чести.

угодна на выъздъ, и крђпкому смъльству привычна.

\section{6. (280) Appvlvs.}

Adspice tollentem rigidos ad sidera vultus, Posticis nixum pedibus, primisque superbe Ad saltum erectis, \& latâ fronte minacem:

Talem Campani, talem dant Appula regna.

\section{Аппулийская}

Зри возносящу свиръпое лице к небу: на задних опершуся Ногахъ, передними высоко к' скоку воздвигнувшуся.

И широким лбом грозну: такову имеют кампанийския народы, Такову во Аппулийском раждають королевствъ.

\section{8. (282) Tvrcus.}

Turcus acer campis, paruis contentus, obesus

Tergore, per lętos celeri pede fertur agellos Sed plerumq[ue] suis (vt fertur) testibus orbus, Atq[ue] iuba tinctus, fulgenti et murice canda ${ }^{63}$ est.

\section{Турской}

Турокъ остръ по поля $м$ малым доволенъ, в заду толсть, по веселы $\mu$ поля $\mu$ скоро носится И часто какъ сказывают без уденъ, гривы крашоной, и хвоста краснаго.

9. (283) Achivvs.

Non minus insignes dant Dorica regna caballos; Quam ${ }^{64}$ quondam quondam, dum fata Deusque sinebant, Insignes habuere viros. namque acris Achivo Est in equo atque alacris concinno in corpore virtus.

\section{Ахивской}

Не менши славных Дорийское гсдрство раждает жеребцов, Древле Богу нечастию попущающу славных имъ людей. Потому что во ахивском жеребць острая И в складном тьль веселая есть доброта.

\footnotetext{
63 Так! Вместо cauda.

64 Так! Вместо quae?
} 
10. (284) Thessalvs.

Hunc fixum quamvis cernas, nullumq[ue] moventem

Ad cursum greßus, similem ne crede figuræ

Hac ex parte: cito namque est velocior Euro:

Cui caput argutum, atque animosæ in pectore vires.

\section{Фессалийский}

Сего хотя стоящаго видишь к бъгу недвижущася.

Не върь по сему образцу. потому что онъ быстряе скораго вътва ${ }^{65}$.

Голова у него весела,

И крђпка в’ грудя $x$ сила.

\section{1. (285). Armenivs.}

Strennuus Armenijs sonipes prognatus in oris,

Gaudet se sævis belli miscere catervis;

Nec timet in medios irrumpere fortiter hostes,

Infestasque acies, \& tela minantia telis.

\section{Арменской 66}

Храброй твердоногой в арменских рожден странах охотник

МЪшатца в жестокие полки воинския.

Не боится крепко в'пасть посредъ неприятелей,

И в’ полки силныя стрђляющия другъ в' друга в’заимно.

\section{2. (286) Natolvs.}

Si pote equumque equitemq[ue] pares conjungere votis,

Quis neget eße uno Natolum Castore dignum;

Quis neget eße unum Natolo Castora dignum?

Namq[ue] equitum ut princeps Castor, sic alter equorum.

\section{Натолийской}

Аще похощешь и лошад и ђздока случит, кто не молвит, что

Натолийская лошад достойна Кастора, и кто не речет, что Касторъ един

Достоинъ натолийской лошади. потому что, яко Кастор

Князь меж ьздоками, такъ лошад между лошадями.

\section{3. (287) Albanvs}

Herbida fundit equos, bellis furialibus aptos

Epirus $^{67}$, calidis voluentes naribus ignes:

Qui vel ad Elæi ${ }^{68}$ metas uel maxima campi

Sudabunt spatia, et spumas flant ore cruentas.

65 Так в ркп., вместо вътрра.

66 На правых полях чернилами написан номер «ЛS» (36).

67 Регион, где ныне расположена Албания.

68 Так! Вместо Elei. Имеется в виду греческая область Элида, в северо-западной части Пелопоннеса, где расположена Олимпия. Ср. у Вергилия (Georgica 3, 202-203): «Hinc vel ad Elei metas et maxima campi / sudabit spatia et spumas aget ore cruentas». Снова создается впечатление, что автор XVI в. воспроизводил Вергилия по памяти. 


\section{Албан'ский}

Травоносный Епиръ родитъ лошадей угодны $x$ к' жестоким война. И пущающих пламя из гарячих ноздрей.

Которыя и по самой далней примътъ, и по долгому в' поляхъ разстоянию Скача не потъютъ, а пьну из рота пускаютъ кроваву.

\section{5. (289) Tvscrs}

Tuscus acer medijs cum sese vallibus effert, Effert argutum caput, auribus emicat, armo Densa iuba in dextro semper jactata recu[m]bit, Concutiens solido paßim frondentia cornu.

\section{Тускийский}

Тускийский быстеръ, когда по валамъ и долинам летаетъ. Къ горђ носитъ изрядную главу, и уши поднимаетъ.

Густая грива всегда на правой сторонъ лежитъ. Ломаеть часто сучья крђпкою головою, когда бъжитъ.

16. (290) Romanvs. / Eqvvs matronalis.

Gloria Romulidum toto licet ampla sit orbe, Stirps tua, Roma, tamen raro laudatur equorum. Parvus amans aulam vestigia mollia ponit Et placidus teneras gaudet portare puellas.

\section{Римский / Конь женской}

Слава римлянъ по всей вселеннЊй хотя пространна. Однако же лошадей одва когда славна, Маль: любить быть при дворђ. и мягко ступаетъ. И не трясетъ, юна дњвица на нем пођзжаетъ.

\section{7. (291) Calaber.}

Fortis, et armipotens calabris prognatus in oris

Est equus, argutumq[ue] cui caput et breuis aluus,

Tergaq[ue] obęsa, feris voluens sub naribus ignem, Sępius et solido tellurem concauat vngue.

\section{Калаврийский}

Крьпокъ: и грудми моченъ, в’ калаврийски (!) рожден страна (!) Конь бываетъ, головы мален'кой, и короткаго брюха.

Лопатки толсты: из ноздрей пламя валитъ.

И крђпким копытомъ землю ломитъ.

\section{8. (292) Insvber}

Cornipedes lectos diues Insubria præbet, Immodicum quibus est latus, et quibus ardua ceruix. Altus honos, oculiq[ue] vago splendore micantes. Continuè calidos qui fumant nare vapores. 


\section{Инсуврийский}

Рогатоногихъ избранных богата Инсувриа раждаетъ. широкобокихъ, и крђпкошейныхъ.

Высокъ головою: очима на всъ стороны позираеть.

Пускаетъ безпрестанно из ноздрей теплой паръ.

19. (293) Sicvlvs

Protulit hunc flavæ gratißima terra parenti, Terra tribus vastum quæ dissecat arcibus aequor:

Ille ad Cecropiæ mißus certamina gentis

Sæpe dedit celeri sessori præmia cursu.

\section{Сицилийский ${ }^{69}$}

Родилсъя сей в' благоприятнъйшей земли.

Которая трема городами пространное раздъляе $m$ море.

Той бывъ на войнъ с Кикропийскими народы.

Всегда Ђздока ударовъ бъгом своим доставляе $m$.

20. (294) Sardonicvs.

Hic maculis varijs paßim distinctus, et altis Sardinijs ${ }^{70}$ fęracis agris euectus aperto Procedens campo spumantia frena remordet Et fremit insultans, impletq[ue] hinnitibus auras.

\section{Сардонийский}

Сей различными крапинами часто накрапанъ.

И по высоким Сардынии плодныя пашням воздвизанъ.

В поляхъ ступая пъноносныя удила кусаетъ.

Шумит наскакая, и воздух ржаниемъ наполняетъ.

\section{1. (295) Corsvs}

Lumine Corsus atrox viso furit, atq[ue] nitentes

Et phaleras duro rejicit, et ephippia dorso.

Lumine nec uiso seßorem admittit, et hoc est

Quod teneant oculos bubulo velamine tectos.

\section{Корсийский}

Сей жестокъ видя свђтъ бђсит'ся.

И попоные съдла с крђпкой спины збивает.

При свђть ни съдъть, не пускаетъ.

И для того буволовымъ покровце $м$ очи ему закрываютъ.

22. (296) Gallicvs.

Ac sua laus etiam Gallis est stirpe ab equorum

Nam quamvis reliquis concedant præpete cursu;

Vix tamen invenias alijs regionibus ullos,

Ponderibus qui ferre pares, quos ${ }^{71}$ Gallice portas.

69 На правых полях чернилами написан номер «ЛЗ» (37).

70 Так! Вместо Sardiniae.

71 Так! Вместо quae? 
Францужской

И французомъ от лошадей своя есть похвала.

Хотя ины $м$ уступають скоры $\mu$ побьгомъ.

Однако же насилу найдешь в ыных странах: подобных к подему.

Тягостей каких: какия фран'цужския кони подымаютъ.

\section{3. (297) Brito.}

Britonijs euectus agris hic gaudet amęnis

Vallibus, et pratis, et apertis gramine campis:

Crinibus et mutilus per iter festinat anhela

Terga sequi, properos gaudens co[n]iungere greßus

\section{Бритонский}

Сей на бритонскихъ поля $x$ веселыхъ, И в' лугахъ, и в долинах пастися.

Безгривой и короткохвостой спъшитъ БЪгущия кони сустичь ходою.

\section{4. (298) Flander.}

Fortes fundit equos, fruticanti Flandria gleba

Diues, et attrito cereales vomere sulcos

Et doctos grauibus terram proscindere rastris,

Nec non et phaleras, et amantes ephippia dorso.

\section{Фляндрийский}

Крђпкихъ раждаетъ лошадей к' пашнъ Фляндриа богата.

И тупымъ плугомъ плодоносны борозды рђзать.

И тяжкою бороною боронить пашню годны

И к' седлу и х конскому наряду пристойны.

\section{8. (302) Saxo.}

Durius ingreditur, et grandia crura reponit

Saxo; et non firmum succussor sede magistrum

Excutit atroces atque efflat naribus ignes,

Audax, sublimis, natibusque et corpore obesus.

\section{Саксонский}

Нелегко ступаетъ, и голени отметываетъ.

И некрьпкого мастера долой збиваетъ.

И жестокое поломя из ноздрей изпускаетъ. смђлъ.

Высокъ. тушею и крестцомъ толстъ.

29. (303) Cimber.

Sint licet Arctoi Boreæ sub flatibus oræ,

Quas, gens dura, tenent horrentes frigore Cimbri;

Dant at equum tamen acrem animis, torvumq[ue] tuentem,

Gaudentem \& riguos greßum glomerare per agros. 


\section{Кимврийский}

Суть севернии кимври, народ жестокой на полночь.

Страшну морозами. однако ж раждает лошадей острых срдцем.

И взоромъ страшныхъ. что и по мокрым

пашня $м$ круги давать могутъ.

\section{7. (311) Mula et Asinus.}

Mularum partus quod prodigiosus habetur, Frigida pigrities causa est, et inepta libido. Ipse Deo hortorum merito mactatur Asellus, Gaudia rugitu sua quod detexerit atro.

\section{Ишакъ и осель}

Рождение чюдно бываетъ, виною есть озяблая льность, и похоть неугодна.

40. (314) Pręscia venturę sic tempestatis equorum

Discurrunt iumenta, vagis hinnitibus auras

Implent, et fumu[m] spirantia naribus atrum

Vngnibus $^{72}$ incuruis viridantia gramina findunt.

Предъ угадывая будущее ненастье разбъгают[-]

ся лошади. и ржаниемъ наполняють воздухъ.

Дымъ черной из ноздрей пущая.

И копытом зеленую траву толоча.

$39 .{ }^{73}$ Sic simul accensi, per inhospita tesqua furore,

Siluestres luctantur equi, sic hispida fetis

Terga capillosis attollunt, mutua duris

Calcibus, et sæuo lacerant dum uiscera morsu.

Такъ дикия лошади возярив'ся бьются в дикихъ пу[-]

стыняхъ. на спинах шерсть аки щетину поднявъ.

Когда жестокими копытами и страшнымъ

Кусаниемъ животъ другъ у друга выпускаютъ.

72 Так! Вместо Vnguibus.

73 Номер листа оторван (вероятно, л. 315). 